\title{
Dyella marensis sp. nov., isolated from cliff soil
}

\author{
Dong Wan Lee and Soon Dong Lee
}

Correspondence

Soon Dong Lee

sdlee@cheju.ac.kr
Department of Science Education, Cheju National University, Jeju 690-756, Republic of Korea

\begin{abstract}
A novel, Gram-negative bacterium, designated $\mathrm{CS} 5-\mathrm{B} 2^{\top}$, was isolated from soil that had been collected from a cliff on Mara Island, Republic of Korea. Phylogenetic analyses based on 16S rRNA gene sequences showed that the strain fell within the radiation of the genus Dyella. The closest relatives were the type strains of Dyella koreensis, Dyella ginsengisoli and Dyella japonica and $16 \mathrm{~S}$ rRNA gene sequence similarities between strain CS5-B2 ${ }^{\top}$ and these strains were 99.0, 97.9 and $97.8 \%$, respectively. The sequence similarities between the novel isolate and other related taxa compared in the phylogenetic analysis were less than $96.7 \%$. The cells of strain CS5-B2 ${ }^{\top}$ were aerobic, oxidase-negative, catalase-positive, motile rods. The temperature range for growth was $20-37{ }^{\circ} \mathrm{C}$, with optimal growth at $30-37^{\circ} \mathrm{C}$. Growth occurred at $\mathrm{pH}$ 5.1-9.1, with optimal growth at $\mathrm{pH} 6.1-9.1 \mathrm{NaCl}$ tolerance for growth was from 1 to $2 \%(\mathrm{w} / \mathrm{v})$.

Ubiquinone-8 was the predominant respiratory lipoquinone. The major fatty acids were iso- $\mathrm{C}_{15: 0}$ and iso- $\mathrm{C}_{17: 1} \omega 9 \mathrm{c}$. The $\mathrm{G}+\mathrm{C}$ content of the DNA was $65.7-66.6 \mathrm{~mol} \%$. The level of DNA-DNA relatedness with $D$. koreensis KCTC $12359^{\top}$ was 20.2 and $29.6 \%$ in duplicate measurements. On the basis of phenotypic features, phylogenetic analysis and DNA-DNA relatedness, a novel species of the genus Dyella is proposed, with the name Dyella marensis sp. nov. The type strain is CS5-B2 ${ }^{\top}\left(=\right.$ JCM $14959^{\top}=$ KCTC $\left.22144^{\top}\right)$.
\end{abstract}

The genus Dyella was first described by Xie \& Yokota (2005). At the time of writing, the genus Dyella contained three recognized species, Dyella japonica (Xie \& Yokota, 2005), Dyella koreensis (An et al., 2005) and Dyella yeojuensis (Kim et al., 2006). A fourth species, Dyella ginsengisoli (Jung et al., 2009) has been described while this paper was in press. This genus is closely related to the genera Fulvimonas, Frateuria and Rhodanobacter in the family Xanthomonadaceae on the basis of $16 \mathrm{~S}$ rRNA gene sequence data.

Strain CS5-B2 ${ }^{\mathrm{T}}$ was isolated from a soil sample that had been collected from a cliff on Mara Island, Republic of Korea. A $1 \mathrm{~g}$ sample was placed into a sterile plastic tube containing $9 \mathrm{ml}$ sterile distilled water. After mixing for 30 min using a tube rotator, followed by serial dilution, $100 \mu \mathrm{l}$ aliquots were transferred to plates of isolation medium, starch-casein agar $\left(\mathrm{l}^{-1}: 10 \mathrm{~g}\right.$ soluble starch, $0.3 \mathrm{~g}$ casein, $2 \mathrm{~g} \mathrm{KNO}_{3}, 2 \mathrm{~g} \mathrm{NaCl}, 2 \mathrm{~g} \mathrm{KH}_{2} \mathrm{PO}_{4}, 0.02 \mathrm{~g} \mathrm{CaCO}_{3}$, $0.05 \mathrm{~g} \mathrm{MgSO}_{4} \cdot 7 \mathrm{H}_{2} \mathrm{O}, 0.01 \mathrm{~g} \mathrm{FeSO}_{4} \cdot 7 \mathrm{H}_{2} \mathrm{O}, 18 \mathrm{~g}$ agar). The plates were incubated at $30{ }^{\circ} \mathrm{C}$ for 2 weeks. A single colony was selected and streaked on YMG agar $\left(1^{-1}: 4 \mathrm{~g}\right.$ yeast extract, $10 \mathrm{~g}$ malt extract, 4 g glucose, $18 \mathrm{~g}$ agar; $\mathrm{pH}$ 7.2) to ensure purity. The pure culture was maintained at -20 and

The GenBank/EMBL/DDBJ accession number of the 16S rRNA gene sequence of strain CS5-B2 ${ }^{\top}$ is AM939778. $^{\circ}$

A supplementary figure showing the cell morphology of strain CS5-B2 ${ }^{\top}$ and a supplementary table detailing the fatty acid profile of strain CS5-B2 ${ }^{\top}$ and related species are available with the online version of this paper.
$-80{ }^{\circ} \mathrm{C}$ as a $20 \%(\mathrm{v} / \mathrm{v})$ glycerol solution. For phenotypic and genetic comparison, D. japonica DSM $16031^{\mathrm{T}}$ and $D$. koreensis KCTC $12359^{\mathrm{T}}$ were used as reference strains.

Cell morphology and motility were observed by using phase-contrast microscopy with cells grown on trypticase soy agar (TSA; Difco) for 3 days. To check for the presence of flagella, cells were stained with $2 \%$ phosphotungstic acid, placed on a gold-coated grid and observed with a transmission electron microscope (JEM-1200EX II; JEOL). Growth was tested on YMG agar, TSA, nutrient agar (Difco) and R2A agar (Difco). The colonies of strain CS5-B2 ${ }^{\mathrm{T}}$ were deep to dark yellow in colour. Soluble pigments were not produced on most of the media tested, with the exception of a yellowish brown pigment on YMG agar. Growth was determined at $4,10,20,30,37$ and $42{ }^{\circ} \mathrm{C}$ and initial $\mathrm{pH} 4.1-12.1$ (with intervals of $1.0 \mathrm{pH}$ unit). $\mathrm{NaCl}$ tolerance for growth was tested on YMG agar supplemented with $1-4 \%(\mathrm{w} / \mathrm{v}) \mathrm{NaCl}$. Gram stain, oxidase and catalase activities, degradation abilities and utilization of carbohydrates were determined by using previously described methods (Lee \& Lee, 2008). Other physiological and biochemical properties were tested using the API 20NE and API ZYM kits (bioMérieux) following the manufacturer's instructions. Cells of strain CS5-B2 ${ }^{\mathrm{T}}$ were aerobic, Gram-negative, motile rods $(0.4-0.5 \times 1.1-3.6 \mu \mathrm{m})$ (see Supplementary Fig. S1, available in IJSEM Online). Cultural, physiological and biochemical characteristics are given in Table 1 and the species description. 
Table 1. Characteristics that differentiate strain $\mathrm{CS} 5-\mathrm{B} 2^{\top}$ from some type strains of species of the genus Dyella

Strains/species: 1, CS5-B2 ${ }^{\mathrm{T}}$; 2, D. japonica DSM $16301^{\mathrm{T}}$ (data from Xie \& Yokota, 2005 and this study); 3, D. koreensis KCTC $12359^{\mathrm{T}}$ (An et al., 2005 and this study); 4, D. yeojuensis R2A16-10 (Kim et al., 2006). All strains are positive for aesculin degradation and utilization of D-glucose, D-mannose, $\mathrm{N}$-acetyl-D-glucosamine and maltose, but negative for indole production, glucose fermentation and utilization of D-arabinose, D-mannitol, gluconate, caprate, adipate, citrate and phenylacetate (API 20NE). All strains are positive for alkaline phosphatase, esterase lipase (C8), leucine arylamidase, valine arylamidase, acid phosphatase, naphthol-AS-BI-phosphohydrolase, $\alpha$-galactosidase, $\alpha$-glucosidase and $\beta$-glucosidase activities but negative for $\beta$-glucuronidase activity (API ZYM). All strains produce acid from D-glucose, but none produce acid from inulin, melezitose, methyl $\alpha$-D-glucoside, methyl $\alpha$-D-mannoside, raffinose, L-rhamnose, salicin, L-sorbose, sucrose, dulcitol, meso-erythritol, glycerol, myoinositol, D-mannitol, D-sorbitol or D-xylitol. +, Positive; -, negative; W, weak; ND, no data available.

\begin{tabular}{|c|c|c|c|c|}
\hline Characteristic & 1 & 2 & 3 & 4 \\
\hline Growth at $10{ }^{\circ} \mathrm{C}$ & - & + & + & + \\
\hline Motility & + & + & - & + \\
\hline \multicolumn{5}{|l|}{ Enzyme activity } \\
\hline Oxidase & - & - & + & + \\
\hline Catalase & + & + & $\mathrm{w}$ & + \\
\hline$\beta$-Galactosidase & + & - & + & + \\
\hline Reduction of nitrate & - & + & + & - \\
\hline \multicolumn{5}{|l|}{ Utilization of: } \\
\hline Malic acid & + & - & + & - \\
\hline \multicolumn{5}{|l|}{ Acid production from: } \\
\hline D-Arabinose & + & - & + & - \\
\hline Cellobiose & + & $\mathrm{w}$ & + & - \\
\hline Lactose & + & - & - & - \\
\hline Maltose & + & + & + & - \\
\hline Trehalose & + & + & + & - \\
\hline D-Xylose & + & - & - & - \\
\hline \multicolumn{5}{|l|}{ Degradation of: } \\
\hline Casein & - & - & + & + \\
\hline Chitin & - & - & + & ND \\
\hline CM-Cellulose & - & - & + & - \\
\hline Starch & + & - & - & - \\
\hline Tyrosine & - & - & - & + \\
\hline \multicolumn{5}{|l|}{ Enzyme activity (API ZYM) } \\
\hline$N$-Acetyl- $\beta$-glucosamidase & - & $\mathrm{w}$ & + & + \\
\hline$\alpha$-Chymotrypsin & + & - & - & - \\
\hline Cystine arylamidase & $\mathrm{w}$ & - & $\mathrm{w}$ & + \\
\hline Esterase $(\mathrm{C} 4)$ & - & + & - & + \\
\hline$\alpha$-Fucosidase & - & + & + & - \\
\hline Lipase (C14) & - & + & - & - \\
\hline$\alpha$-Mannosidase & - & + & - & - \\
\hline Trypsin & - & + & - & - \\
\hline DNA G $+C$ content $(\mathrm{mol} \%)$ & $65.7-66.6$ & $63.4-64$ & 63.8 & 63.0 \\
\hline
\end{tabular}

Genomic DNA was extracted and purified as described by Hopwood et al. (1985). The $16 \mathrm{~S}$ rRNA gene was amplified and purified according to the method of Lee \& Lee (2008).
Multiple alignments of sequences were performed using CLUSTAL_X (Thompson et al., 1997). A phylogenetic tree was constructed with the neighbour-joining method (Saitou \& Nei, 1987) from evolutionary distances calculated with the coefficient of Jukes \& Cantor (1969). The confidence levels of the tree topology were evaluated by bootstrap analysis (Felsenstein, 1985) using 1000 replications. The neighbour-joining tree was compared with trees constructed with the maximum-likelihood (Felsenstein, 1981) and maximum-parsimony (Fitch, 1971) methods.

The partial 16S rRNA gene sequence (1377 nt) of strain $\mathrm{CS} 5-\mathrm{B} 2^{\mathrm{T}}$ determined in this study was compared with the corresponding sequences of members of the genus Dyella and related taxa. A neighbour-joining tree (Fig. 1) based on $16 \mathrm{~S}$ rRNA gene sequences showed that strain CS5-B2 ${ }^{\mathrm{T}}$ lies within the radiation of the genus Dyella. The closest relatives were $D$. koreensis $\mathrm{BB} 4^{\mathrm{T}}(99.0 \%$ sequence similarity), D. ginsengisoli Gsoil $3046^{\mathrm{T}}(97.9 \%)$ and D. japonica

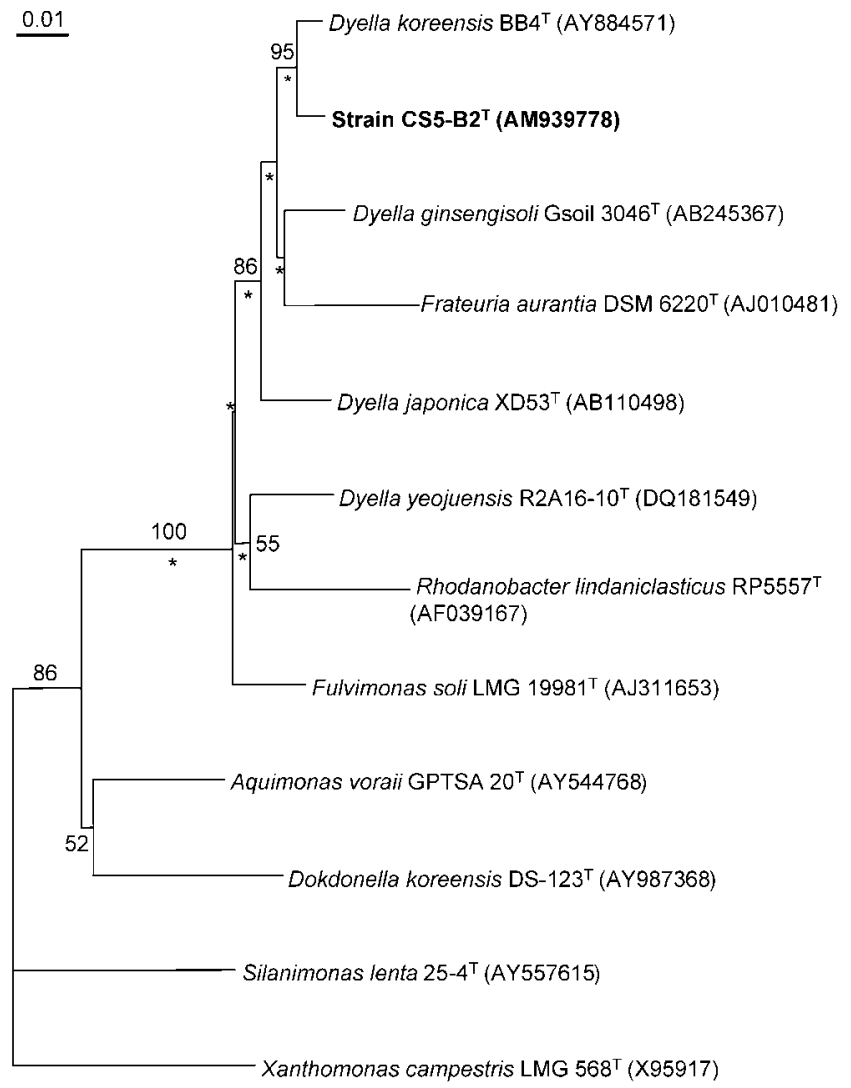

Fig. 1. A neighbour-joining phylogenetic tree based on $16 \mathrm{~S}$ rRNA gene sequences showing the position of strain CS5-B2 ${ }^{\top}$ within the radiation encompassing species of the genus Dyella and related taxa. Xanthomonas campestris LMG $568^{\top}$ was used as an outgroup. Bootstrap percentages (from 1000 replications) greater than $50 \%$ are shown at branching points. *, Branches also found in trees generated with maximum-likelihood (Felsenstein, 1981) and maximum-parsimony (Fitch, 1971) methods. Bar, 1 inferred nucleotide substitution per 100 nucleotides. 
$\mathrm{XD}^{\mathrm{T}}{ }^{\mathrm{T}}$ (97.8\%). The 16S rRNA gene sequence similarities between the novel isolate and the type strains of related taxa used in the phylogenetic analysis were less than $96.7 \%$.

Cell biomass for chemotaxonomic analyses was obtained from cultures grown in YMG broth for 3 days at $30{ }^{\circ} \mathrm{C}$. Respiratory lipoquinones were extracted according to Collins (1985) and identified by HPLC (Kroppenstedt, 1985). For analysis of cellular fatty acids, strain CS5-B2 ${ }^{\mathrm{T}}$ and the type strains of $D$. koreensis and $D$. japonica were grown on TSA for 3 days at $30{ }^{\circ} \mathrm{C}$. Cellular fatty acid methyl esters were prepared and analysed according to the standard protocol of the Microbial Identification System (version 6; MIDI). Ubiquinone-8 is the predominant respiratory lipoquinone. The cellular fatty acid profile of strain $\mathrm{CS} 5-\mathrm{B} 2{ }^{\mathrm{T}}$ consisted of saturated, branched and hydroxy fatty acids (see Supplementary Table S1 in IJSEM Online). The major fatty acids were iso- $\mathrm{C}_{15: 0}$ $(23.2-27.0 \%)$ and iso- $\mathrm{C}_{17: 1} \omega 9 c(23.4-26.1 \%)$. The cellular fatty acid profiles of $D$. koreensis KCTC $12359^{\mathrm{T}}$ and $D$. japonica DSM $16031^{\mathrm{T}}$ as determined in this study contained smaller amounts of iso- $\mathrm{C}_{17: 0}$ (10.7-12.4 and $7.5-12.4 \%$, respectively) than previously reported (15.626.0 and $20.0 \%$, respectively) (An et al., 2005; Xie \& Yokota, 2005).

The DNA G $+\mathrm{C}$ contents of strain $\mathrm{CS} 5-\mathrm{B} 2^{\mathrm{T}}$, D. koreensis KCTC $12359^{\mathrm{T}}$ and D. japonica DSM $16031^{\mathrm{T}}$ were analysed by HPLC (Mesbah et al., 1989) and the values were determined by using the following formula: $\mathrm{G}+\mathrm{C}$ mol$\%=[(1+\mathrm{dT} /$ $\left.\mathrm{dC})^{-1} \times 100+(1+\mathrm{dA} / \mathrm{dG})^{-1} \times 100\right] / 2 . \quad$ Each experiment was performed in duplicate with DNA prepared from independent cultures. The DNA G+C content was 65.7$66.7 \mathrm{~mol} \%$ for strain CS5-B2 ${ }^{\mathrm{T}}, 61.1-62.2 \mathrm{~mol} \%$ for $D$. koreensis and $62.6-63.2 \mathrm{~mol} \%$ for $D$. japonica. The values for $D$. koreensis and D. japonica were slightly lower in this study than previously reported figures (63.8 and 63.4-64 mol\%, respectively) (An et al., 2005; Xie \& Yokota, 2005).

Along with low $16 \mathrm{~S}$ rRNA gene sequence similarity, strain CS5-B2 ${ }^{\mathrm{T}}$ differed from $D$. japonica DSM $16031^{\mathrm{T}}$ in many characteristics, such as nitrate reduction, utilization of malic acid, acid production from D-arabinose, lactose and D-xylose, starch hydrolysis and several enzyme activities (Table 1). Therefore, DNA-DNA relatedness was determined only between strain CS5-B2 ${ }^{\mathrm{T}}$ and $D$. koreensis KCTC $12359^{\mathrm{T}}$, as described previously (Lee \& Lee, 2008). The DNA-DNA hybridization values in duplicate measurements were 20.2 and $29.6 \%$, lower than the threshold value of $70 \%$ recommended for the definition of bacterial species (Wayne et al., 1987). The physiological and biochemical characteristics that distinguish the novel isolate from $D$. koreensis KCTC $12359^{\mathrm{T}}$ are also given in Table 1.

On the basis of the phenotypic, phylogenetic and DNADNA hybridization analysis presented, it is clear that strain CS5-B2 ${ }^{\mathrm{T}}$ represents a novel species of the genus Dyella, for which the name Dyella marensis sp. nov. is proposed.

\section{Description of Dyella marensis sp. nov.}

Dyella marensis (ma.ren'sis. N.L. fem. adj. marensis of Mara Island, Jeju, Republic of Korea, on which the type strain was isolated).

Cells are aerobic, Gram-negative, oxidase-negative, catalasepositive, motile rods $(0.4-0.5 \times 1.1-3.6 \mu \mathrm{m})$. Colonies are irregular, undulate, umbonate, dark yellow in colour and reach $2.5-4.0 \mathrm{~mm}$ in diameter after 3 days of incubation. Temperature range for growth is $20-37{ }^{\circ} \mathrm{C}$, with good growth at $30-37{ }^{\circ} \mathrm{C}$. Growth occurs at $\mathrm{pH}$ 5.1-9.1, with good growth at $\mathrm{pH}$ 6.1-9.1. NaCl tolerance for growth is up to $2 \%$ $(w / v)$. Gelatin liquefaction is observed. DNA and elastin are hydrolysed but hypoxanthine and xanthine are not. Arginine dihydrolase and urease are not detected. Acid is produced from dextrin, D-galactose and D-mannose but not from Larabinose and D-fructose. Data for other physiological and biochemical properties are given in Table 1 . Ubiquinone- 8 is the predominant respiratory lipoquinone. Major fatty acids are iso- $\mathrm{C}_{15: 0}$ and iso- $\mathrm{C}_{17: 1} \omega 9 \mathrm{c}$.

The type strain, CS5-B2 ${ }^{\mathrm{T}}\left(=\mathrm{JCM} 14959^{\mathrm{T}}=\right.$ KCTC $\left.22144^{\mathrm{T}}\right)$, was isolated from a soil sample that had been collected from a cliff on Mara Island, Republic of Korea. The DNA $\mathrm{G}+\mathrm{C}$ content of the type strain is $65.7-66.6 \mathrm{~mol} \%$.

\section{Acknowledgements}

This work was supported by the 21C Frontier Microbial Genomics and Application Center Program, Ministry of Science \& Technology, Republic of Korea. The authors are thankful to Dr R. Pukall (Deutsche Sammlung von Mikroorganismen und Zellkulturen $\mathrm{GmbH}$ ) for providing the type strain of D. japonica and to Dr J.-S. Lee (Korean Collection for Type Cultures) for providing the type strain of D. koreensis.

\section{References}

An, D.-S., Im, W.-T., Yang, H.-C., Yang, D.-C. \& Lee, S.-T. (2005). Dyella koreensis sp. nov., a $\beta$-glucosidase-producing bacterium. Int $J$ Syst Evol Microbiol 55, 1625-1628.

Collins, M. D. (1985). Analysis of isoprenoid quinones. Methods Microbiol 18, 329-366.

Felsenstein, J. (1981). Evolutionary trees from DNA sequences: a maximum likelihood approach. J Mol Evol 17, 368-376.

Felsenstein, J. (1985). Confidence limits on phylogenies: an approach using the bootstrap. Evolution 39, 783-791.

Fitch, W. M. (1971). Toward defining the course of evolution: minimum change for a specific tree topology. Syst Zool 20, 406-416.

Hopwood, D. A., Bibb, M. J., Chater, K. F., Kieser, T., Bruton, C. J., Kieser, H. M., Lydiate, D. J., Smith, C. P., Ward, J. M. \& Schrempf, H. (1985). Genetic Manipulation of Streptomyces: a Laboratory Manual. Norwich: John Innes Foundation.

Jukes, T. H. \& Cantor, C. R. (1969). Evolution of protein molecules. In Mammalian Protein Metabolism, vol. 3, pp. 21-132. Edited by H. N. Munro. New York: Academic Press.

Jung, H.-M., Ten, L. N., Kim, K.-H., An, D. S., Im, W.-T. \& Lee, S.-T. (2009). Dyella ginsengisoli sp. nov., isolated from soil of a ginseng field in South Korea. Int J Syst Evol Microbiol 59, 460-465. 
Kim, B.-Y., Weon, H.-Y., Lee, K.-H., Seok, S.-J., Kwon, S.-W., Go, S.-J. \& Stackebrandt, E. (2006). Dyella yeojuensis sp. nov., isolated from greenhouse soil in Korea. Int J Syst Evol Microbiol 56, 2079-2082.

Kroppenstedt, R. M. (1985). Fatty acid and menaquinone analysis of actinomycetes and related organisms. In Chemical Methods in Bacterial Systematics (Society for Applied Bacteriology Technical Series vol. 20), pp. 173-199. Edited by M. Goodfellow \& D. E. Minnikin. New York: Academic Press.

Lee, D. W. \& Lee, S. D. (2008). Aeromicrobium ponti sp. nov., isolated from seawater. Int J Syst Evol Microbiol 58, 987-991.

Mesbah, M., Premachandran, U. \& Whitman, W. B. (1989). Precise measurement of the $\mathrm{G}+\mathrm{C}$ content of deoxyribonucleic acid by high-performance liquid chromatography. Int J Syst Bacteriol 39, 159-167.
Saitou, N. \& Nei, M. (1987). The neighbor-joining method: a new method for reconstructing phylogenetic trees. Mol Biol Evol 4, 406-425.

Thompson, J. D., Gibson, T. J., Plewniak, F., Jeanmougin, F. \& Higgins, D. G. (1997). The CLUSTAL_X windows interface: flexible strategies for multiple sequence alignment aided by quality analysis tools. Nucleic Acids Res 25, 4876-4882.

Wayne, L. G., Brenner, D. J., Colwell, R. R., Grimont, P. A. D., Kandler, O., Krichevsky, M. I., Moore, L. H., Moore, W. E. C., Murray, R. G. E. \& other authors (1987). International Committee on Systematic Bacteriology. Report of the ad hoc committee on reconciliation of approaches to bacterial systematics. Int J Syst Bacteriol 37, 463-464.

Xie, C.-H. \& Yokota, A. (2005). Dyella japonica gen. nov., sp. nov., a gamma-proteobacterium isolated from soil. Int J Syst Evol Microbiol 55, 753-756. 